\title{
EFEK PEMBERIAN EKSTRAK ETANOL RIMPANG TEMU PUTIH (Curcuma zedoaria (Berg.) Roscoe) TERHADAP PERUBAHAN KADAR PROTEIN TOTAL DAN ALKALI FOSFATASE PADA TIKUS (Rattus norvegicus) YANG DIPAPARKAN ASAP ROKOK
}

\author{
Fauziah Amin, Nur Inda Yanti, Sartini, Sumarheni \\ Fakultas Farmasi, Universitas Hasanuddin, Makassar
}

Kata Kunci :

Asap rokok, Curcuma zedoaria Berg. Roscoe, protein total, alkali fosfatase



Diterima 31-12-2018

Korespondensi

\section{Sumarheni}

sumarheni@unhas.ac.id

Copyright

C 2018 Majalah Farmasi Farmakologi Fakultas

Farmasi - Makassar

Diterbitkan tanggal

31-12-2018

Dapat Diakses Daring

Pada:

http://journal.unhas.ac.id

/index.php/mff

\begin{abstract}
ABSTRAK
Temu putih (Curcuma zedoaria (Berg.) Roscoe) telah banyak digunakan secara tradisional sebagai pengobatan penyakit. Temu putih diketahui memiliki aktivitas antioksidan yang berpotensi memperbaiki kerusakan sel. Tujuan penelitian ini yaitu mengevaluasi efek ekstrak temu putih (ETP) melalui perubahan kadar protein total dan alkali fosfatase (ALP) pada tikus yang dipaparkan asap rokok. Sebanyak 15 ekor tikus dibagi menjadi 5 kelompok $(n=3)$ yaitu kelompok kontrol negatif, kontrol positif, kelompok induksi asap rokok dan ETP $70 \mathrm{mg} / 200 \mathrm{gBB}$, kelompok induksi asap rokok dan ETP 105 $\mathrm{mg} / 200 \mathrm{gBB}$, dan kelompok pemberian ETP $105 \mathrm{mg} / 200 \mathrm{gBB}$. Perlakuan dilakukan selama 30 hari. Pada hari ke-0 dan hari ke-30, diambil darah tikus untuk mengevaluasi perubahan kadar protein total dan ALP. Hasil penelitian menunjukkan pemberian ETP secara peroral pada hewan coba tikus yang telah dipaparkan asap rokok menurunkan kadar protein total secara signifikan dengan nilai $p=0,038$ dan 0,004 $(\mathrm{p}<0,05)$ masing-masing setelah pemberian ETP dosis $70 \mathrm{mg} / 200 \mathrm{gBB}$ dan $105 \mathrm{mg} / 200 \mathrm{gBB}$. Pemberian dosis yang sama juga menunjukkan signifikansi penurunan kadar ALP dengan nilai $p=0,003$ dan 0,001 $(\mathrm{p}<0,05)$ pada tikus yang terpapar asap rokok. Kesimpulan penelitan ini adalah ekstrak temu putih 70 $\mathrm{mg} / 200 \mathrm{gBB}$ dan $105 \mathrm{mg} / 200 \mathrm{gBB}$ dapat menurunkan kadar protein total dan ALP tikus yang terpapar asap rokok selama 30 hari.
\end{abstract}

\section{PENDAHULUAN}

Merokok merupakan masalah serius dalam dunia kesehatan yang masih menjadi salah satu penyebab terbesar kematian di dunia. Berdasarkan data World Health Organization tahun 2018, lebih dari 1,1 triliun orang merokok dan didominasi oleh pria dibanding wanita. Lebih dari 6 juta kasus kematian di dunia disebabkan karena konsumsi rokok secara langsung dan sekitar 890.000 diantaranya merupakan hasil dari paparan asap rokok pada orang bukan perokok (secondhand smoke) (1). Di Indonesia, sedikitnya 25.000 kematian perokok pasif yang dikarenakan paparan asap dari perokok lain (2). Asap rokok mengandung berbagai oksidan seperti radikal bebas oksigen atau reactive oxygen species (ROS) dan aldehida volatil yang memungkinkan terjadinya kerusakan pada biomolekul (3). Asap rokok dengan kandungan sejumlah besar radikal bebas, mampu memulai atau mempromosi kerusakan oksidatif pada level seluler. Kerusakan oksidatif pada tingkat DNA juga telah diamati setelah pemaparan asap rokok (4).

Merokok dianggap sebagai faktor resiko menderita kanker hati dengan meningkatkan resiko sirosis dan dapat mempengaruhi perkembangan penyakit hati kronis. Hal tersebut dapat dipicu karena akumulasi ROS yang berkepanjangan $(5,6)$. Beberapa penanda kerusakan pada hati dapat dilihat melalui perubahan kadar protein total dan alkali fosfatase (ALP). Pada penelitian sebelumnya diketahui bahwa terdapat perbedaan signifikan rata-rata kadar protein total pada orang perokok dan tidak perokok $(p<0,001)$, serta diketahui kadar protein total pada perokok pasif lebih besar $13 \%$ secara signifikan daripada perokok aktif $(7,8)$. Beberapa penelitian pada manusia menunjukkan peningkatan yang signifikan secara statistik pada kadar dalam alkali fosfatase dan beberapa enzim lainnya pada perokok aktif, serta dapat memperburuk efek patogenik alkohol pada hati $(9,10)$.

Curcuma zedoaria atau temu putih merupakan tanaman dari famili Zingiberaceae yang tumbuh terutama di negara-negara Asia dan telah digunakan secara tradisional untuk pengobatan dispepsia, gangguan menstruasi, dan bahkan untuk mengatasi kanker (11). Beberapa studi menunjukkan bahwa senyawa fenolik yang terkandung dalam temu putih memiliki aktivitas antioksidan serta memiliki aktivitas antiinflamasi dan antikarsinogenik $(12,13,14)$. Pada penelitian tahun 2005, diketahui ekstrak etanol temu putih dan kurang aktif pada sel normal dengan $\mathrm{IC}_{50}$ sebesar 6,05, 17,84 dan 55,50 $\mu \mathrm{g} / \mathrm{ml}$ masingmasing terhadap sel kanker paru, kanker prostat dan sel normal (15). Rimpang temu putih juga telah diketahui memiliki LD50 sebesar 1000 $\mathrm{mg} / \mathrm{kgBB}(16)$. Evaluasi efek antioksidan ekstrak temu putih telah banyak diidentifikasi, akan tetapi efeknya terhadap paparan asap rokok pada hewan coba tikus (Rattus norvegicus) belum banyak memiliki potensi yang tinggi melawan sel kanker 
diteliti. Sehingga pada penelitian ini diamati efek pemberian temu putih untuk mengurangi efek radikal bebas dari pemaparan asap rokok melalui parameter kadar protein total dan alkali fosfatase.

\section{METODE PENELITIAN}

\section{Preparasi Ekstrak Temu Putih (ETP)}

Sampel rimpang temu putih diambil dari daerah Kabupaten Sidrap, Sulawesi Selatan. Sampel rimpang temu putih dideterminasi di Laboratorium Biologi, Fakultas MIPA Universitas Negeri Makassar. Pembuatan ekstrak temu putih diawali dengan pembuatan simplisia rimpang temu putih. Simplisia rimpang temu putih selanjutnya diayak menggunakan ayakan nomor 18 dan dilanjutkan dengan proses maserasi satu bagian serbuk simplisia dalam 10 bagian pelarut etanol $70 \%$. Maserat dipisahkan menggunakan kain saring dan proses maserasi diulangi 2 kali dengan pelarut yang sama selama 2 hari. Ekstrak cair yang telah ditampung kemudian dipekatkan dengan menggunakan rotary evaporator. Setelah itu disimpan didalam desikator hingga diperoleh ekstrak kental (17).

\section{Pemberian Dosis Ekstrak Temu Putih (ETP)}

Dosis ETP yang diberikan untuk mencit yaitu $500 \mathrm{mg} / \mathrm{kgBB}$ dan $750 \mathrm{mg} / \mathrm{kgBB}$ (18). Dosis tersebut dikonversikan kedalam dosis untuk hewan coba tikus, sehingga didapatkan dosis $70 \mathrm{mg} / 200 \mathrm{gBB}$ tikus dan $105 \mathrm{mg} / 200 \mathrm{gBB}$ tikus. ETP diberikan dalam bentuk suspensi $7 \%$ dan $10,5 \%$ secara p.o.

\section{Penggunaan Hewan Coba}

Kelayakan etik penelitian penggunaan hewan coba telah mendapat persetujuan dari Komisi Etik Fakultas Kedokteran Universitas Hasanuddin dengan surat no. 292/H4.8.4.5.31/PP36-KOMETIK/2018. Hewan coba yang digunakan dalam penelitian adalah tikus putih (Rattus norvegicus) jantan sebanyak 15 ekor dengan bobot badan 150 -250 gram dibagi kedalam 5 kelompok $(n=3)$. Hewan coba ditempatkan didalam kandang dengan asupan makanan dan air ad libitum setiap hari. Tikus diadaptasikan selama 7 hari sebelum dilakukan penelitian.

Kelompok 1 merupakan kelompok kontrol negatif dengan pemaparan asap rokok dan pemberian larutan koloidal NaCMC 1\%. Kelompok 2 merupakan kelompok kontrol positif, yaitu pemberian pemaparan asap rokok dan pemberian vitamin $\mathrm{C}$ dan NaCMC 1\%. Kelompok 3 merupakan kelompok pemberian pemaparan asap rokok dan ETP $70 \mathrm{mg} / 200 \mathrm{gBB}$. Kelompok 4 merupakan kelompok pemberian pemaparan asap rokok dan ETP $105 \mathrm{mg} / 200 \mathrm{gBB}$ Kelompok 5 merupakan kelompok evaluasi pemberian ETP $105 \mathrm{mg} / 200 \mathrm{gBB}$ terhadap tikus sehat. Pemberian NaCMC, ETP, dan vitamin $C$ diberikan secara per oral. Perlakuan hewan coba dilakukan selama 30 hari.

\section{Pemaparan Asap Rokok}

Pemberian induksi asap rokok pada hewan coba dilakukan didalam smoking chamber, sesuai prosedur penelitian yang dilakukan Sugeng et al pada tahun 2010 (19), dengan modifikasi ukuran smoking chamber yaitu 50 × 60 × $40 \mathrm{~cm}$. Rokok merek ' $\mathrm{X}$ ' yang dipaparkan pada hewan coba merupakan rokok kretek tanpa filter dan mengandung $39 \mathrm{mg}$ tar dan 2,5 mg nikotin. Tikus dipaparkan asap rokok setiap hari sebanyak 10 batang rokok selama kurang lebih 30 menit. Pemaparan asap rokok diberikan selama 30 hari berturutturut.

\section{Evaluasi Kadar Protein Total dan ALP}

Sebelum diberi perlakuan, pada hari ke-0 darah diambil terlebih dahulu melalui vena lateral pada ekor tikus untuk dijadikan sebagai kadar protein total dan ALP awal tikus. Selama perlakuan dilakukan, bobot badan tikus ditimbang secara berkala dan dilakukan pengecekan setiap hari. Setelah itu, darah kemudian diambil kembali melalui vena lateral pada ekor tikus untuk diukur kadar protein total dan ALP akhir tikus pada hari ke-30. Analisis fungsi hati dilakukan dengan pengukuran kadar ALP dalam serum menggunakan reagen diagnostik dan ABX Pentra 400.

\section{Analisis Statistika}

Data yang telah diperoleh dianalisis menggunakan software SPSS 20 dengan metode Kolmogorov-smirnov untuk melihat distribusi normal data. Data yang terdistribusi normal, dilanjutkan dengan metode analisis one way ANOVA kemudian dilanjutkan dengan uji post hoc menggunakan uji signifikansi $L S D$. $P$-value $<0,05$ dinyatakan signifikan secara statistik.

\section{HASIL DAN PEMBAHASAN}

Serbuk simplisia rimpang temu putih (Curcuma zedoaria (Berg.) Roscoe) sebanyak 300 gram diekstraksi menggunakan metode maserasi dengan pelarut etanol $70 \%$. Maserat yang diperoleh selanjutnya dipekatkan menggunakan rotary vacuum evaporator dan disimpan di dalam desikator hingga diperoleh hasil seperti pada Tabel 1.

\begin{tabular}{lll} 
Tabel 1. Hasil Ekstraksi Temu Putih (Curcuma zedoaria (Berg.) Roscoe) \\
\hline Bobot Simplisia (gram) & 300 \\
\hline Bobot Ekstrak (gram) & 82,3825 & \\
\hline Rendamen Ekstrak (\%) & 27,461 & \\
\hline Organoleptis & $\begin{array}{l}\text { Ekstrak kental, berwarna coklat } \\
\text { kehitaman, dan berbau khas }\end{array}$ \\
\hline
\end{tabular}

Metode pengukuran protein total menggunakan ABX Pentra 400 menggunakan prinsip reaksi biuret. Ikatan peptide dari protein bereaksi dengan ion copper II dalam larutan basa membentuk kompleks biru-violet (disebut reaksi biuret), dimana tiap copper membentuk kompleks dengan 5 atau 6 ikatan peptide. Tartrat ditambahkan sebagai stabilisator dengan iodide digunakan untuk mencegah auto-reduksi dari kompleks copper basa. Warna yang terbentuk berhubungan dengan konsentrasi protein dan diukur pada panjang gelombang 520-560 $\mathrm{nm}$.

Berdasarkan Tabel 2, terjadi perubahan kadar protein total pada hari ke-0 dan hari ke-30 setelah pemberian perlakuan terhadap hewan coba ikus (Rattus norvegicus). Hari ke-0 menunjukkan kadar protein total hewan coba sebelum diberikan perlakuan dan hari ke-30 menunjukkan kadar protein total hewan coba setelah 30 hari diberi perlakuan. Adapun profil perubahan kadar protein total awal dan akhir dapat dilihat pada Gambar 1.

Pada analisis uji one-way ANOVA menunjukkan hasil signifikansi yang baik, yaitu $0,007(\mathrm{p}<0,05)$. Hasil tersebut menunjukkan bahwa pemberian ekstrak temu putih memberikan perbedaan secara nyata perubahan kadar protein total pada tikus yang telah diinduksikan asap rokok.

Pada uji $L S D$, didapatkan hasil bahwa kontrol negatif signifikan terhadap kelompok 2 (kontrol positif), kelompok 3 (asap rokok + ekstrak 70mg/200gBB) dan kelompok 4 (asap rokok + ekstrak 105mg/200gBB) dengan nilai $\mathrm{p}=0,001$; 0,038 ; dan $0,004(\mathrm{p}<0,05)$ dan tidak berbeda nyata dengan kelompok 5 (pemberian ekstrak $105 \mathrm{mg} / 200 \mathrm{gBB}$ ). Sehingga dapat disimpulkan bahwa pemberian ekstrak $105 \mathrm{mg} / 200 \mathrm{gBB}$ tidak memberikan efek yang berbeda nyata dengan kelompok tikus yang dipaparkan asap rokok, serta pemberian dosis ekstrak $70 \mathrm{mg} / 200 \mathrm{gBB}$ dan $105 \mathrm{mg} / 200 \mathrm{gBB}$ pada tikus yang telah terpapar asap rokok mampu memberikan penurunan kadar protein total secara signifikan. 
Tabel 2. Hasil Pengukuran Kadar Protein Total

\begin{tabular}{|c|c|c|c|c|c|}
\hline \multirow{2}{*}{\multicolumn{2}{|c|}{ Kelompok Perlakuan }} & \multirow{2}{*}{ Replikasi } & \multicolumn{2}{|c|}{ Kadar Total Protein (g/dL) } & \multirow{2}{*}{$\begin{array}{c}\Delta \text { Kadar Total Protein (Akhir-awal) } \\
\text { (g/dL) }\end{array}$} \\
\hline & & & Hari ke-0 & Hari ke-30 & \\
\hline \multirow{4}{*}{1} & \multirow{4}{*}{$\begin{array}{l}\text { Kontrol negatif (asap } \\
\text { rokok) }\end{array}$} & 1 & 5,40 & 5,80 & 0,40 \\
\hline & & 2 & 5,40 & 5,60 & 0,20 \\
\hline & & 3 & 5,30 & 5,80 & 0,50 \\
\hline & & Rata-rata \pm SD & $5,37 \pm 0,06$ & $5,73 \pm 0,12$ & \\
\hline \multirow{4}{*}{2} & \multirow{4}{*}{$\begin{array}{l}\text { Kontrol positif (asap } \\
\text { rokok + vitamin C) }\end{array}$} & 1 & 6,20 & 5,40 & $-0,80$ \\
\hline & & 2 & 6,10 & 5,90 & $-0,20$ \\
\hline & & 3 & 6,50 & 5,70 & $-0,80$ \\
\hline & & Rata-rata \pm SD & $6,27 \pm 0,21$ & $5,67 \pm 0,25$ & \\
\hline \multirow{4}{*}{3} & \multirow{4}{*}{$\begin{array}{l}\text { Asap rokok + ekstrak } \\
\text { dosis } 70 \mathrm{mg} / 200 \mathrm{gBB}\end{array}$} & 1 & 5,40 & 5,30 & $-0,10$ \\
\hline & & 2 & 5,50 & 5,00 & $-0,50$ \\
\hline & & 3 & 5,80 & 5,60 & $-0,20$ \\
\hline & & Rata-rata \pm SD & $5,57 \pm 0,21$ & $5,3 \pm 0,30$ & \\
\hline \multirow{4}{*}{4} & \multirow{4}{*}{$\begin{array}{l}\text { Asap rokok + ekstrak } \\
\text { dosis } 105 \mathrm{mg} / 200 \mathrm{gBB}\end{array}$} & 1 & 5,40 & 5,00 & $-0,40$ \\
\hline & & 2 & 5,80 & 5,60 & $-0,20$ \\
\hline & & 3 & 5,70 & 5,10 & $-0,60$ \\
\hline & & Rata-rata \pm SD & $5,63 \pm 0,21$ & $5,23 \pm 0,32$ & \\
\hline \multirow{4}{*}{5} & \multirow{4}{*}{$\begin{array}{c}\text { Ekstrak dosis } \\
105 \mathrm{mg} / 200 \mathrm{gBB}\end{array}$} & 1 & 5,60 & 5,50 & $-0,10$ \\
\hline & & 2 & 5,50 & 5,70 & 0,20 \\
\hline & & 3 & 5,60 & 5,70 & 0,10 \\
\hline & & Rata-rata \pm SD & $5,57 \pm 0,06$ & $5,63 \pm 0,12$ & \\
\hline
\end{tabular}

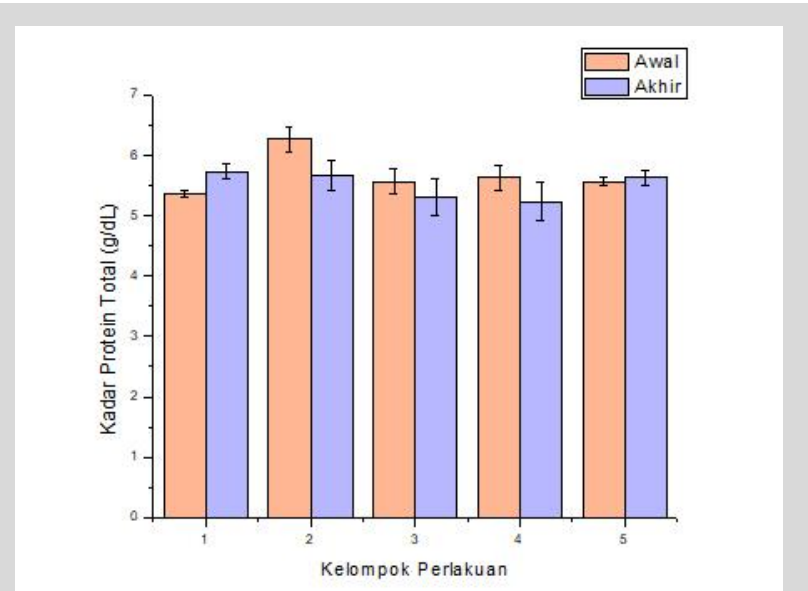

Gambar 1. Gambaran perubahan rata-rata \pm SD kadar protein total pada hewan coba tikus sebelum dan setelah pemberian perlakuan Keterangan:

Kelompok 1: Kontrol negatif,

Kelompok 2: Kontrol positif,

Kelompok 3: Asap rokok + ekstrak dosis 70mg/200gBB,

Kelompok 4: Asap rokok + ekstrak dosis $105 \mathrm{mg} / 200 \mathrm{gBB}$

Kelompok 5: Ekstrak 105mg/200gBB.

Berdasarkan persentase penurunan kadar protein total, ekstrak dosis 105mg/200gBB memberikan efek penurunan kadar protein total lebih banyak dibandingkan dengan ekstrak $70 \mathrm{mg} / 200 \mathrm{gBB}$ pada hewan yang telah dipaparkan asap rokok, yaitu 4,85\% untuk dosis $70 \mathrm{mg} / 200 \mathrm{gBB}$ dan $7,10 \%$ untuk dosis $105 \mathrm{mg} / 200 \mathrm{gBB}$. Adapun penurunan kadar kelompok lainnya, yaitu kelompok vitamin $C$ sebesar 9,57\%. Sehingga berdasarkan perhitungan persentase penurunan kadar protein total, dapat disimpulkan bahwa kedua dosis ekstrak yang diberikan pada hewan coba tidak melebihi perubahan kadar yang terjadi pada kontrol positif.

Peningkatan yang terjadi pada kadar protein total setelah pemberian paparan asap rokok, sejalan dengan penelitian yang dilakukan oleh Zainulabdeen et al dan Abdul-razzq et al, bahwa terdapat perbedaan signifikan rata-rata kadar protein total pada orang perokok dan tidak perokok $(p<0,001)$ masing-masing yaitu $8.192 \pm 1.421$ dan $6.175 \pm 1.008$, serta ditemukan adanya penurunan pada tingkat total protein sebesar $13 \%$ dengan rata-rata kadar protein total pada perokok pasif $10.46 \pm 0.136$ dan perokok aktif $9.063 \pm 0.080$ $(7,10)$.

Adapun peningkatan kadar total protein yang terjadi, disebabkan adanya paparan asap tembakau dapat mengganggu sintesis protein karena pengaruhnya pada fungsi hati. Sehingga, perubahan dalam keseimbangan oksidatif tersebut menstimulasi tubuh untuk menghasilkan protein yang bertanggung jawab untuk menyeimbangkan kembali (20).

Berdasarkan Tabel 3, dapat dilihat perubahan kadar ALP pada hari ke-0 dan hari ke-30 setelah pemberian perlakuan terhadap tikus (Rattus norvegicus). Hari ke-0 menunjukkan kadar ALP hewan coba sebelum diberikan perlakuan dan hari ke-30 menunjukkan kadar ALP hewan coba setelah 30 hari diberi perlakuan. Adapun profil perubahan kadar ALP awal dan akhir dapat dilihat pada Gambar 2.

Adapun persentase penurunan kadar pada kelompok ekstrak dosis $70 \mathrm{mg} / 200 \mathrm{gBB}$ dan $105 \mathrm{mg} / 200 \mathrm{gBB}$ yaitu $21,05 \%$ dan $35 \%$, serta persentase penurunan kadar kelompok lainnya, yaitu kelompok vitamin C sebesar 44,45\% daan kelompok pemberian ekstrak $105 \mathrm{mg} / 200 \mathrm{gBB}$ sebesar $43,75 \%$. Sehingga berdasarkan perhitungan persentase penurunan kadar ALP, dapat disimpulkan bahwa kedua dosis ekstrak yang diberikan pada hewan coba tidak melebihi perubahan kadar yang terjadi pada kontrol positif. Adapun kelompok 5 (ekstrak $105 \mathrm{mg} / 200 \mathrm{gBB}$ ) berdasarkan data persentase penurunan kadar ALP, memberikan efek penurunan kadar ALP lebih baik dari pada kelompok ekstrak yang diberikan pada tikus yang telah terpapar asap rokok.

Pada analisis uji one-way ANOVA menunjukkan hasil signifikansi yang baik untuk dilakukan uji lanjutan, yaitu dengan $p$-value $=0,002(\mathrm{p}<0,05)$ pada kadar ALP hari ke-0 dan ALP hari ke-30. Hasil penelitian diatas sejalan dengan hasil penelitian yang dilakukan oleh Abdul-razaq et al (2013) bahwa terjadi peningkatan kadar ALP pada perokok secara signifikan dengan $p$-value 0,001. Demikian pula pada penelitian yang dilakukan oleh Wannamethee et al bahwa terdapat hubungan antara kebiasaan merokok dengan kadar enzim ALP di hati secara signifikan $(r=0,15 ; p<0,0001)$.

Pada uji $L S D$, didapatkan hasil bahwa kontrol negatif signifikan terhadap semua kelompok perlakuan $(\mathrm{p}<0,05)$. Adapun nilai signifikansi terhadap kelompok kontrol positif, 
Tabel 3. Hasil Pengukuran Kadar ALP

\begin{tabular}{|c|c|c|c|c|c|}
\hline \multirow{2}{*}{\multicolumn{2}{|c|}{ Kelompok Perlakuan }} & \multirow{2}{*}{ Replikasi } & \multicolumn{2}{|c|}{ Kadar ALP (U/L) } & \multirow{2}{*}{$\Delta$ Kadar ALP (Akhir-awal) (U/L) } \\
\hline & & & Hari ke-0 & Hari ke-30 & \\
\hline \multirow{4}{*}{1} & \multirow{4}{*}{$\begin{array}{l}\text { Kontrol negatif (asap } \\
\text { rokok) }\end{array}$} & 1 & 4,00 & 7,00 & 3,00 \\
\hline & & 2 & 3,00 & 8,00 & 5,00 \\
\hline & & 3 & 4,00 & 5,00 & 1,00 \\
\hline & & Rata-rata \pm SD & $3,67 \pm 0,58$ & $6,67 \pm 1,53$ & \\
\hline \multirow{4}{*}{2} & \multirow{4}{*}{$\begin{array}{l}\text { Kontrol positif (asap } \\
\text { rokok + vitamin C) }\end{array}$} & 1 & 5,00 & 4,00 & $-1,00$ \\
\hline & & 2 & 7,00 & 2,00 & $-5,00$ \\
\hline & & 3 & 6,00 & 4,00 & $-2,00$ \\
\hline & & Rata-rata $\pm S D$ & $6,00 \pm 1,00$ & $3,33 \pm 1,15$ & \\
\hline \multirow{4}{*}{3} & \multirow{4}{*}{$\begin{array}{l}\text { Asap rokok + ekstrak } \\
\text { dosis } 70 \mathrm{mg} / 200 \mathrm{gBB}\end{array}$} & 1 & 6,00 & 5,00 & $-1,00$ \\
\hline & & 2 & 7,00 & 6,00 & $-1,00$ \\
\hline & & 3 & 6,00 & 4,00 & $-2,00$ \\
\hline & & Rata-rata \pm SD & $6,33 \pm 0,58$ & $5,00 \pm 1,00$ & \\
\hline \multirow{4}{*}{4} & \multirow{4}{*}{$\begin{array}{l}\text { Asap rokok + ekstrak } \\
\text { dosis } 105 \mathrm{mg} / 200 \mathrm{gBB}\end{array}$} & 1 & 8,00 & 5,00 & $-3,00$ \\
\hline & & 2 & 7,00 & 5,00 & $-2,00$ \\
\hline & & 3 & 5,00 & 3,00 & $-2,00$ \\
\hline & & Rata-rata \pm SD & $6,67 \pm 1,53$ & $4,33 \pm 1,15$ & \\
\hline \multirow{4}{*}{5} & \multirow{4}{*}{$\begin{array}{l}\text { Ekstrak dosis } \\
105 \mathrm{mg} / 200 \mathrm{gBB}\end{array}$} & 1 & 6,00 & 4,00 & $-2,00$ \\
\hline & & 2 & 5,00 & 3,00 & $-2,00$ \\
\hline & & 3 & 5,00 & 2,00 & $-3,00$ \\
\hline & & Rata-rata \pm SD & $5,33 \pm 0,578$ & $3,00 \pm 1,00$ & \\
\hline
\end{tabular}

ekstrak dosis 70mg/200gBB dan ekstrak 105mg/200gBB setelah pemaparan asap rokok yaitu 0,000; 0,003 dan 0,001.

Pada kelompok evaluasi ekstrak, tanpa pemaparan asap rokok, juga terjadi perbedaan secara nyata terhadap penurunan kadar ALP. Sehingga dapat disimpulkan bahwa dosis ekstrak $70 \mathrm{mg} / 200 \mathrm{gBB}$ maupun $105 \mathrm{mg} / 200 \mathrm{gBB}$ mampu menyebabkan terjadinya penurunan kadar ALP secara signifikan.

Adapun keterbatasan penelitian ini yaitu pemaparan asap rokok yang diberikan pada hewan coba tikus secara bersamaan didalam smoking chamber menyebabkan tidak diketahuinya kadar atau jumlah asap rokok yang dihirup oleh masing-masing tikus. Pada pengamatan visual, hewan coba tikus pada saat diberi paparan asap rokok, menjadi gelisah dan mata memerah. Pengamatan tersebut sama halnya dengan pengamatan penelitian yang dilakukan oleh Ponzoni et al bahwa pengamatan kebiasaan hewan coba perekat yang dipaparkan asap rokok mengalami kegelisahan dan kelelahan (21).

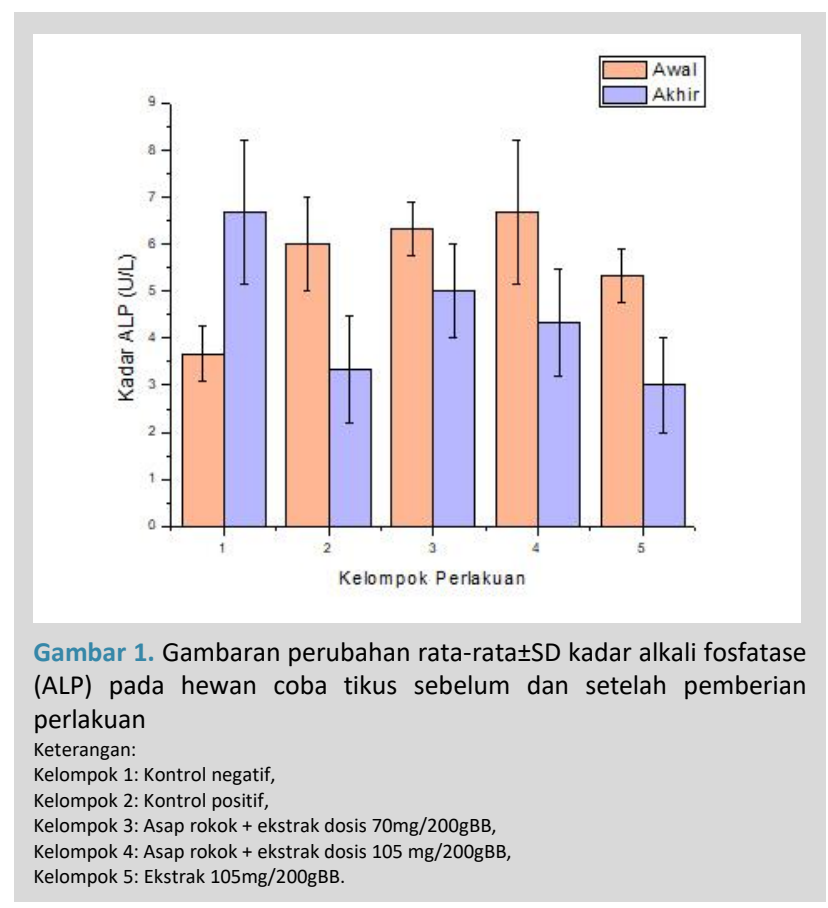

\section{KESIMPULAN}

Dari penelitian diatas dapat disimpulkan bahwa pemberian ekstrak rimpang temu putih $70 \mathrm{mg} / 200 \mathrm{gBB}$ dan $100 \mathrm{mg} / 200 \mathrm{gBB}$ secara signifikan menurunkan kadar protein total masing-masing dengan $\mathrm{p}=0,038$ dan $0,004(\mathrm{p}<0,05)$ pada hewan coba tikus yang terkena paparan asap rokok selama 30 hari, serta pada dosis $70 \mathrm{mg} / 200 \mathrm{gBB}$ dan $105 \mathrm{mg} / 200 \mathrm{gBB}$ menunjukkan secara signifikan masingmasing dengan $\mathrm{p}=0,003$ dan 0,001 ( $p$-value $<0,05)$.

\section{DAFTAR PUSTAKA}

1. World Health Organization. Fact Sheets of Cigarette Smoke [internet]. WHO; 2018. Available from: http://www.who.int/news-room/factsheets/detail/tobacco

2. Riskesdas. Laporan Riset Kesehatan Dasar 2013. Badan Penelitian dan Pengembangan Kesehatan Kementerian Kesehatan RI. 2013.

3. Tsuchiya, M., Asada, A., Kasahara, E., Sato, E.F., Shindo, M. \& Inoue, $M$. Smoking a Single Cigarette Rapidly Reduces Combined Concentrations of Nitrate and Nitrite and Concentrations of Antioxidants in Plasma. American Heart Association. 2002:1155-1157. doi: 10.1161/hc1002.105935

4. Chen, Z., Wang, D., Liu, X. \& Cao, Y. Oxidative DNA damage is involved in cigarette smoke-induced lung injury in rats. Environt Health Prev Med. 2015;20(5):318-324.

5. Droge, W. Free Radicals in The Physiological Control of Cell Function. Physiol Rev. 2002.

6. Kusumawardani, A., Sarwendah, K., Rahmad, L., Millah, N.U., Herliyani, N., Sutrisno, B. Sitotoksik Asap Rokok pada Kornea Tikus Putih Wistar yang Diberi Ekstrak Kunyit (Curcuma Domestica Val.). Jurnal Sain Veteriner. 2013;31(1):89-99.

7. Zainulabdeen, J. A. \& Saad, A. A. Effects of Smoking on Proteins Level and Alpha Amylase Activity in Sera of Iraqi Narghile Smokers. Mustansiriyah J. Sci. 2014;25(3):33.

8. Roohi, N \& Mehjabeen, S.A. Effects of cigarette smoking on serum proteins profile in male active and passive smokers. Punjab Univ. J. Zool. 2017;32(2):209-215.

9. Wannamethee, S. G. \& Shaper, A. G. Original Article Cigarette smoking and serum liver enzymes: the role of alcohol and inflammation. Annals of Clinical Biochemistry. 2010;47:321-326.

10. Abdul-razaq, S. N. \& Ahmed, B. M. Effect of cigarette smoking on liver function test and some other related parameters. Zanco J. Med. Sci. 2013;17(3):556-62

11. Lobo, R., Prabhu, K. S. \& Shirwaikar, A. Curcuma zedoaria Rosc. (white turmeric): a review of its chemical, pharmacological and ethnomedicinal properties Ethnomedicinal or Traditional Uses. Journal of Pharmacy and Pharmacology. 2009;61:13-21. doi: 10.1211/jpp/61.01.0003

12. Srimal, R. C. \& Dhawan, B. N. Pharmacology of diferuloylmethane (curcumin), a non-steroidal anti inflammatory agent. J. Pharm Pharmacol. 1973;25:447-452.

13. Sharm, O. P. Antioxidant activity of curcumin and related compounds. Biochem Pharmacol. 1976;25:1811-1812. 
14. Ruby, A. J., Kuttan, G., Babu, K.D., Rajasekharan, K.N., Kuttan, R. Antitumor and antioxidant activity of natural curcuminoids. Cancer Lett. 1995; 94: 79-83.

15. Saetung, A., Itharat, A., Dechsukum, C., Wattanapiromsakul, C., Niwat, P.R. Cytotoxic activity of Thai medicinal plants for cancer treatment. J Sc Technol. 2005;27(Suppl. 2):469-478. doi: 10.1055/s-0028-1084234

16. Prasad, P. P., Chakraborty, M., Haldar, S., Majumder, P., Haldar, P. K. Evaluation Of Anti Cancer Potential of Methanol Extract of Curcuma zedoaria. Asian J Pharm Clin Res. 2015;7(5):309-13.

17. Departemen Kesehatan RI. Farmakope Herbal Indonesia. Edisi I. Jakarta; 2008.

18. Murwanti R. \& Meiyanto E. Efek Ekstrak Etanol Rimpang Temu Putih (Curcuma zedoaria Rosc.) Terhadap Pertumbuhan Tumor Paru Fase Post
Inisiasi Pada Mencit Betina Diinduksi Benzo(a)piren. Majalah Farmasi Indonesia. 2004;15(1):7-12.

19. Sugeng, S.U., Tiono, H. dan Anandaputri, V.N. Pengaruh Pasta Tomat (Solanum lycopersicum) terhadap Diameter Tubulus Seminiferus Mencit (Mus musculus) Galur DDY yang Terpajan Asap Rokok Berfilter. JKM. 2010;10(1):47-54.

20. Wrześniak, M. Kepinska, M. Królik, M. \& Milnerowicz, H. The Influence of Tobacco Smoke on Protein and Metal Levels in the Serum of Women during Pregnancy. Japan. PLOS ONE. 2016;11(8):161-342.

21. Ponzoni, L, Moretti, M, Sala, M, Fasoli, F, Mucchietto, V. Different physiological and behavioural effects of e-cigarette vapour and cigarette smoke in mice. J Euroneuro. 2015;25(10):1775-1786. 